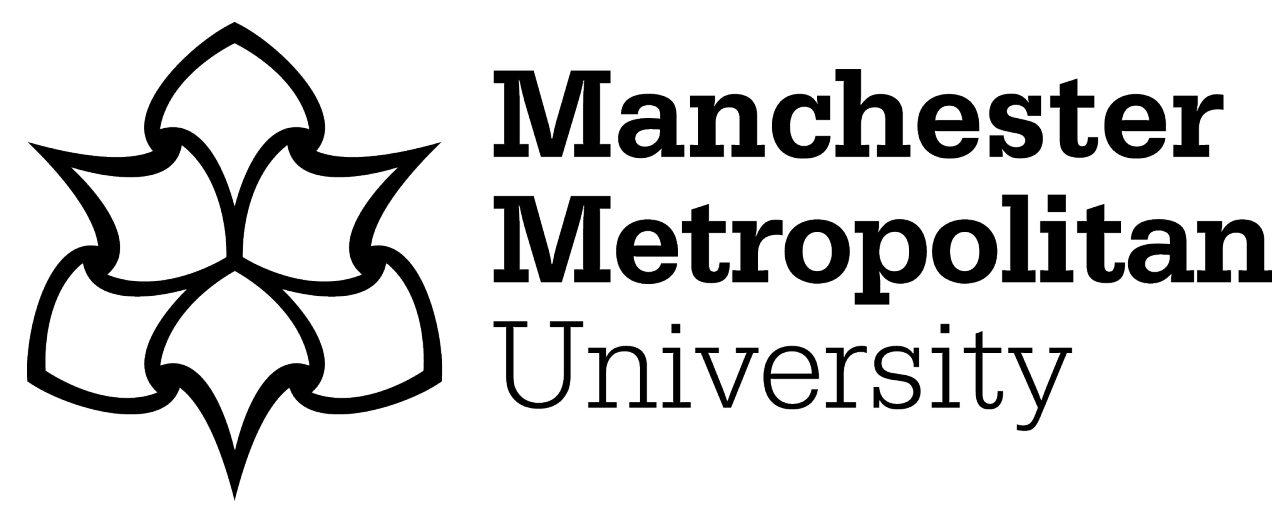

Scelles, Nicolas ORCID logoORCID: https://orcid.org/0000-0002-6177-5307 and Andreff, Wladimir (2019) Determinants of national men's football team performance: A focus on goal difference between teams. International Journal of Sport Management and Marketing, 19 (5/6). pp. 407-424. ISSN 14758962

Downloaded from: https://e-space.mmu.ac.uk/624572/

Version: Accepted Version

Publisher: Inderscience

DOI: https://doi.org/10.1504/IJSMM.2019.104168

Please cite the published version 


\section{Determinants of national men's football team performance: A focus on goal difference between teams}

Nicolas Scelles and Wladimir Andreff

Nicolas Scelles

N.Scelles@mmu.ac.uk

Sport Policy Unit

Manchester Metropolitan University

Business School, All Saints Campus

Manchester, M15 6BH

UK

Wladimir Andreff

andreff@,club-internet.fr

Observatoire de l'Economie du Sport

Ministère des Sports

95 avenue de France

75650 Paris Cedex 13

France

Nicolas Scelles

He is Senior Lecturer in the Sport Policy Unit, Department of Economics, Policy and International Business, Faculty of Business and Law, Manchester Metropolitan University, UK. He holds a PhD in sports economics from the University of Caen, France. He was awarded a prize from the French professional football clubs union in 2010 for his thesis. He has various 
research publications and communications in the areas of sports economics, finance, management and marketing. He has published in international journals such as Applied Economics, Applied Economics Letters, Economics Bulletin, Ekonomicheskaya Politika / Economic Policy, International Journal of Financial Studies, International Journal of Sport Finance, International Journal of Sport Management and Marketing, Journal of Sports Economics, Learning \& Individual Differences, Managing Sport and Leisure, Movement \& Sport Sciences - Science \& Motricité, Personality \& Individual Differences, Soccer \& Society, Sport, Business and Management: An International Journal, Sport in Society and Team Performance Management: An International Journal. He is board member of Intellekt. Innovatsii. Investitsii (Intelligence. Innovations. Investments), International Journal of Sport Marketing and Sponsorship, Managing Sport and Leisure, Movement \& Sport Sciences Science \& Motricité and Sport, Business and Management: An International Journal. He is also member of the European Sports Economics Association (ESEA) and the Boards of the International Society for Sports Sciences in the Arab World (I3SAW) and the Scientific Council of the French Observatory of the Sports Economy.

Wladimir Andreff

Professor Emeritus at the University Paris 1 Panthéon-Sorbonne.

Honorary President and former President (2002-05) of International Association of Sport Economists, Honorary President of the European Sports Economics Association, former President of the French Economic Association (2007-08) and Honorary Member and former President of the European Association for Comparative Economic Studies (1997-98).

Member of the French National Council for Physical and Sport Activities (2001-08). President of the Scientific Council at the Observatory of the Sports Economy, French Ministry for Sports, since May 2015. 
Research and teaching areas: sports economics, economics of (post-communist) transition, international economics.

Seating in 9 scientific journal editorial boards and serving as a peer-reviewer with 32 scientific journals.

Author of 12 books ( 5 in sports economics), 449 scientific articles (71 peer-reviewed) of which 146 in sports economics, and editor of 17 books ( 5 in sports economics), published or translated in 18 languages.

Last books in sports economics:

Mondialisation économique du sport. Manuel de référence en Economie du sport, De Boeck, Bruxelles 2012 (Globalisation of the sports economy: Reference textbook in sports economics, used for teaching in all French speaking countries).

Last sports economics books as an editor:

Disequilibrium Sports Economics: Competitive Imbalance and Budget Constraints, Edward Elgar, Cheltenham 2015.

Recent Development in the Economics of Sport, 2 volumes, Edward Elgar, Cheltenham 2011.

Contemporary Issues in Sports Economics: Participation and Professional Team Sports, Edward Elgar, Cheltenham 2011.

Editor of the book series 'New Horizons in the Economics of Sports' with Edward Elgar, Cheltenham and of 'Pivot in Sports Economics' with Palgrave.

Co-author of two official reports in sports economics:

The Economic Importance of Sport in Europe: Financing and Economic Impact, 14th Informal Meeting of European Sports Ministers, Council of Europe, Strasbourg, April 1994, 208 pages. Public and Private Financing of Sport, Report for the French Presidency of European Union, presented at the meeting of 27 European Sports Ministers, Biarritz, November 2008, 120 pages. 


\title{
Determinants of national men's football team performance: A focus on goal difference between teams
}

\begin{abstract}
In the literature, several articles have focused on the socioeconomic and sporting determinants of national men's football team performance measured through FIFA points. In the present paper, knowledge improvement comes from focusing on goal difference in individual games. The main objectives are to verify that game outcomes have some determinants similar to FIFA points but also game specific variables (home advantage and sporting prizes). The methodology is based on regressions including all games over the 2011-2013 period (2584 observations). The results confirm that game outcomes have some determinants similar to FIFA points but also game specific variables.
\end{abstract}

Keywords: international men's football; team performance; socioeconomic determinants; sporting determinants; game determinants; goal difference; home advantage; sporting prizes; FIFA points; policy implications. 


\section{Introduction}

In men's football, head coaches and players regularly say that "in one game, everything is possible". However, long-term hierarchies such as the FIFA ranking show large differences between teams. The objectives of this paper are to verify that, despite these elements, the determinants of long-term performance are valid for short-term/game outcomes and the latter have also game specific variables (home advantage and sporting prizes). Our sample encompasses 2584 international men's football games over the 2011-2013 period. Our dependent variable is the goal difference between teams.

The remainder of the paper reads as follows. First, the literature about the measurement and determinants of national men's football team performance is reviewed in order to identify usually significant determinants. Second, a model specification is outlined, based on previously tested as well as newly-introduced determinants. Third, data are described and correlations between variables are exhibited. Fourth, results are reported. Fifth, their implications are discussed before concluding.

\section{Literature review}

\subsection{Measurement of national men's football team performance}

A number of studies have focused on the socioeconomic and sporting determinants of national men's football team performance (Allan and Moffat, 2014; Andreff and Andreff, 2015; Baur and Lehmann, 2007; Berlinschi et al., 2013; Gelade and Dobson, 2007; Hoffmann et al., 2002, 2006; Houston and Wilson, 2002; Kuper and Szymanski, 2012; Leeds and Leeds, 2009; Macmillan and Smith, 2007; Monks and Husch, 2009; Paul and Mitra, 2008; Papanikos, 2015; 
Torgler, 2004; Yamamura, 2009, 2012) ${ }^{1}$. This performance was generally measured with the FIFA (Fédération Internationale de Football Association) ranking or points accumulated by a country at a particular point in time. The number of points per game depends on game outcome, game importance, the strength of the opponent and the strength of the regional confederation (FIFA, n.d.). Average number of points is calculated over four years with a weighting according to the date of the game: $100 \%$ for game average from past 12 months, $50 \%$ from previous year, 30\% from year 3 and 20\% from year 4 (games older than 4 years deleted) (FIFA, n.d.).

Two studies did not rely on FIFA rankings or points: Monks and Husch (2009) tested the sporting (and not socioeconomic) determinants of the World Cup tournament final standing, while Andreff and Andreff (2015) tested the determinants of the World Cup semi-finalists. Four other researches have dealt with the determinants of national men's football team performance with a focus on individual games (Kuper and Szymanski, 2012; Papanikos, 2015; Paul and Mitra, 2008; Torgler, 2004). Torgler (2004) measured this performance with a win dummy, Kuper and Szymanski (2012) and Papanikos (2015) with goal difference, and Paul and Mitra (2008) with both.

\subsection{Determinants of national men's football team performance}

The literature about the socioeconomic and sporting determinants of FIFA rankings/points and international games surveyed below is not exhaustive since two articles (Paul and Mitra, 2008; Torgler, 2004) dealing with sporting determinants during each specific game (shots on goal, fouls, corner kicks...) are not covered. Indeed, the model developed in this article attempts to

\footnotetext{
${ }^{1}$ Hoffmann et al. (2006) compared international women's and men's football. Congdon-Hohman and Matheson (2013), Jacobs (2014) and Torgler (2008) are not listed as they focused only on international women's football.
} 
control for socio-economic and sporting determinants at kick off and not intra-game. However, it is worth noting that Torgler (2004) found a significant positive impact of home advantage on winning a game in the 2002 World Cup (home advantage was not tested by Paul and Mitra (2008) whereas Kuper and Szymanski (2012) also found a significant positive impact of home advantage on performance in international games).

To the best of the authors' knowledge, Houston and Wilson (2002) and Hoffmann et al. (2002) published the first articles focusing on socioeconomic and sporting determinants of international football performance. Houston and Wilson (2002) took as right-hand side explanatory variables Gross Domestic Product (GDP) per capita, its square in order to verify the existence of a decreasing return effect, population, the number of years since a national football federation has joined FIFA, World Cup and Youth World Cup appearances. They found a significant positive impact for GDP, population, World Cup and Youth World Cup appearances, no significant impact for the number of years since a national football federation has joined FIFA and a significant negative impact of the squared GDP.

The impact of income through GDP and its square, and population were tested by Hoffmann et al. (2002) as well; they also introduced (temperature $\left.-14^{\circ} \mathrm{C}\right)^{2}$ as an explanatory variable because previous research had shown that $14^{\circ} \mathrm{C}$ is the "ideal" temperature for playing a football game, the occurrence of having hosted the World Cup, a dummy for Latin countries (Central and South American countries, Spain and Portugal) and an interactive term for Latin countries and population. They found a significant positive impact of GDP (consistent with Houston and Wilson, 2002), the occurrence of having hosted the World Cup and the interactive term for Latin countries and population, no significant impact of population (contrary to Houston and Wilson, 2002) and Latin countries alone, and a significant negative impact of squared GDP (consistent with Houston and Wilson, 2002) and (temperature $\left.-14^{\circ} \mathrm{C}\right)^{2}$. 
Hoffmann et al. (2006) kept significant variables (except squared GDP) and found similar results.

The following studies introduced new explanatory variables but they also kept and found significant results for:

- population (Allan and Moffat, 2014; Berlinschi et al., 2013; Kuper and Szymanski, 2012; Leeds and Leeds, 2009; Papanikos, 2015; Yamamura, 2009, 2012),

- GDP per capita (Allan and Moffat, 2014; Berlinschi et al., 2013; Gelade and Dobson, 2007; Kuper and Szymanski, 2012; Leeds and Leeds, 2009; Macmillan and Smith, 2007; Papanikos, 2015: Yamamura, 2009),

- (temperature - 14)2 (Allan and Moffat, 2014; Berlinschi et al., 2013; Macmillan and Smith, 2007),

- experience as captured by the number of years as a FIFA member (Yamamura, 2009, 2012), federation age (Allan and Moffat, 2014; Gelade and Dobson, 2007), year of foundation (Berlinschi et al., 2013), year of the first international game (Macmillan and Smith, 2007) or the number of games played by a country in its history (Kuper and Szymanski, 2012).

Among new determinants, Gelade and Dobson (2007) tested the number of football players per country instead of population and found a significant positive impact. MacMillan and Smith (2007) controlled for the former Soviet republics (except Russia) which had national teams prior to the Soviet era before being dissolved in the early 1920s and reappearing in the 1990s. They found a significant negative impact that they explained by a comparatively early start for these republics but later political developments.

Leeds and Leeds (2009) integrated a large number of variables capturing the effect of a nation's political regime, colonial heritage and national institutions:

- currently or former communist countries (currently and former being distinguished), 
- Freedom House (combination of two indices, one for political rights and one for civil liberties),

- members of OECD (Organisation for Economic Co-operation and Development),

- countries which obtained their independence after 1900 from France, the Netherlands, Portugal and United Kingdom,

- colonizers (England, France, the Netherlands, Portugal and Spain),

- oil-exporting countries (Nigeria, Russia, Mexico, Norway, Iran and the Gulf states: Bahrain, Kuwait, Iraq, Oman, Qatar, Saudi Arabia and the United Arab Emirates),

- confederations (CAF for Confédération Africaine de Football, AFC for Asian Football Confederation, UEFA for Union Européenne de Football Association, OFC for Oceania Football Confederation, CONMEBOL for Confederación Sudamericana de Fútbol and CONCACAF for Confederation of North, Central American and Caribbean Association Football, chosen as reference),

- and the number of teams from each country qualified in the round of 32 for the main continental club competition.

Leeds and Leeds (2009) found a significantly positive impact of former communist countries, independence from United Kingdom, colonizers, oil-exporting countries, CONMEBOL, the number of teams in the African, Asian and European Champions Leagues and in the Copa Toyota Libertadore. They also found a significantly negative impact of currently communist countries, independence from the Netherlands, AFC and OFC.

More recently, Allan and Moffat (2014) introduced a manager import index for foreign managers: managerimport $_{i}=$ domesticpoints $_{i}$ - leaguepoints ${ }_{i}$, with domesticpoints d $_{i}$ the ranking points of the manager's domestic league $i$ (i.e. the league for his country of origin) and leaguepoints $s_{i}$ the ranking points of league $i$ in the country for which he manages the national team. They found a significant negative impact of the manager import index. Their 
interpretation was that cultural differences between management and players are difficult to overcome in international football so national sides should employ domestic managers. Papanikos (2015) incorporated the level of democracy. He explained goal difference between teams and included FIFA points as an explanatory variable in his model specification.

\section{Model specification}

A Goal difference and a related ordered dependent variable - i.e. win for team $i$ / draw / win for team $j$ (called then Winner / draw) - equations are specified and then estimated with variables from or inspired by the literature review and six variables not tested yet as determinants of national men's football team performance. The former are:

- Population: $\left(\log P O P_{i}-\log P O P_{j}\right) / \log \left[\min \left(P O P_{i}, P O P_{j}\right)\right]$, where $P O P_{i}$ stands for the population of team $i$ 's nation and $P O P_{j}$ for the population of team j's nation.

- GDP per capita: $\left(\log G D P_{i}-\log G D P_{j}\right) / \log \left[\min \left(G D P_{i}, G D P_{j}\right)\right]$, where $G D P_{i}$ stands for the GDP per capita of team $i$ 's nation and $G D P_{j}$ for the GDP per capita of team $j$ 's nation.

To account for diminishing returns to both variables, their natural logarithms are used (see e.g. Leeds and Leeds, 2009).

- Democracy: DEM corresponds to the democracy index (evaluated on a scale of 10) for a country, thus $D E M_{i}-D E M_{j}$, where $D E M_{i}$ stands for the democracy index of team $i$ 's nation and $D E M_{j}$ for the democracy index of team $j$ 's nation.

- Climate $\left(\left[\text { temperature }-14^{\circ} \mathrm{C}\right]^{2}\right): C L I_{i}-C L I_{j}$, 
where $C L I_{i}$ stands for the climate of team $i$ 's nation and $C L I_{j}$ for the climate of team $j$ 's nation.

- Experience: EXP equals the number of matches played by a national men's football team in its history (friendlies included), thus $\left(\log E X P_{i}-\log E X P_{j}\right) / \log \left[\min \left(E X P_{i}, E X P_{j}\right)\right]$, where $E X P_{i}$ stands for the number of matches played by the national men's football team $i$ and $E X P_{j}$ for the number of matches played by the national men's football team $j$.

As for population and GDP per capita, to account for diminishing returns to experience, its natural logarithm is used.

- Percentage of players $(P P L)$ as the number of football players in a country $(N P L)$ divided by its population: $N P L_{i} / P O P_{i}-N P L_{j} / P O P_{j}$,

where $N P L_{i} / P O P_{i}$ stands for the number of football players of team $i$ 's nation divided by its population and $N P L_{j} / P O P_{j}$ for the number of football players of team $j$ 's nation divided by its population.

The expectation is that a large population is not enough to perform in international football while the percentage of players within this population should be a crucial determinant of performance.

- Home advantage as a variable equal to 1 if team $i$ plays home, -1 if team $j$ plays home, 0 otherwise.

- A confederation effect as a variable equal to 1 for a team $i$ from a specific confederation among the six existing FIFA confederations (AFC, CAF, CONCACAF, CONMEBOL, OFC and UEFA), and -1 for a team $j$ from another confederation. For example, if team $i$ is Brazil and team $j$ is Japan, CONMEBOL takes the value 1 and AFC the value -1 . If the two teams belong to the same confederation, the variable for this confederation is equal to 0 since there is no confederation effect differentiating both teams. For example, if team $i$ is England and team $j$ is France, UEFA takes the value 0 . 
The newly-tested determinants are:

- Quality of players $(Q P L)$ as the number of players who are on the roster of the 10 most valuable European football clubs and have been fielded in at least 20 games per season: $Q P L_{i}-Q P L_{j}$ where $Q P L_{i}$ stands for the number of 'quality' players of team $i$ 's nation and $Q P L_{j}$ for the number of 'quality' players of team $j$ 's nation.

In 2011, 2012 and 2013, the 10 most valuable clubs were Real Madrid, Manchester United, FC Barcelona, Arsenal, Bayern Munich, AC Milan, Chelsea, Juventus, Manchester City and Liverpool (in 2013, more than $\$ 650$ million for each team against $\$ 520$ million for the $11^{\text {th }}$ - Tottenham; Ozanian, 2013). The underlying assumption is that the best players have an incentive to play in those teams with the largest financial resources to pay them.

- Five variables related to the nature of the sporting prize associated to a specific match. Broadly speaking, sporting prize refers to three main situations: a competitive game with at least one team having something to compete for (for games with national teams, this can be a qualification for the next round, the first position in the group stage in competitions such as the FIFA men's World Cup so as to avoid in the next round the team supposed to be the best in another group, or winning the competition); or a competitive game with both teams having nothing to compete for (teams already qualified or eliminated); or a friendly game. This notion of sporting prize has become important in the literature since 2004 (Andreff and Scelles, 2015; Budzinski and Pawlowski, 2014; Buraimo and Simmons, 2015; Kringstad and Gerrard, 2004a, 2004b, 2005, 2007; Pawlowski and Anders, 2012; Pawlowski and Nalbantis, 2015; Pawlowski et al., 2018; Scelles, 2017; Scelles, Desbordes et al., 2011; Scelles, Durand et al., 2011; Scelles et al., 2013a, 2013b, 2016). The five variables are as follows: 
1. Prize for both teams: a variable equal to 1 if team $i$ is favourite, -1 if team $j$ is favourite in a match with sporting prizes for the two teams.

A team is considered as favourite if there is a difference of 0.1 or more between the two opponents in betting odds. The choice of using 0.1 as a cut-off is based on the fact that betting odds provided by BetBase1 (the source used) are the means from different betting companies and the latter are more likely to agree on the favourite when the absolute mean difference between teams is at least $0.1^{2}$. When betting odds are not available, values are allocated to teams only in those cases where an obvious favourite could be identified.

2. Prize difference for the favourite: a variable equal to 1 if team $i$ is favourite, -1 if team $j$ is favourite when it occurs that the favourite team has a sporting prize whereas the underdog has no sporting prize.

3. Prize difference for the underdog: a variable equal to 1 if team $i$ is the favourite, -1 if team $j$ is the favourite, the latter having no sporting prize whereas the underdog has a sporting prize.

4. No prize in a competitive match: a variable equal to 1 if team $i$ is favourite, -1 if team $j$ is favourite in a competitive match without sporting prize for any of the two teams.

5. No prize in a friendly match: a variable equal to 1 if team $i$ is favourite, -1 if team $j$ is favourite in a friendly match.

All aforementioned variables are included in our initial set of models. In a second set, an additional variable is incorporated: the FIFA point difference between team $i$ and team $j$ before the game (points updated by FIFA every month). The aim is to observe if this variable increases the explanatory power of the models and / or captures the impact of other variables.

\section{Data description and correlations}

\footnotetext{
${ }^{2}$ Replacing the cut-off by 0.01 does not change the results.
} 
The sample used for testing the above-specified models gathers all match-specific data from 2011 to 2013 (2884 matches). Data for Goal difference (GD), Winner / draw (WD), Experience (EXP), Percentage of players (PPL), Home advantage (HA) and Confederation effect have been collected or calculated from FIFA sources, Population (POP) is available on the United Nations website, GDP per capita (GDP) on the International Monetary Fund website, Climate (CLI) on the World Bank website, Democracy (DEM) on the Economist website, Quality of players (QPL) on ESPN and Wikipedia, and Prize for both teams (PBT), Prize difference for the favourite (PDF), Prize difference for the underdog (PDU), No prize in competitive match (NPC) and No prize in friendly match (NPF) on BetBase1. FIFA point differences (FIFA) have been found on Football Rankings Info. Some data were not available for Percentage of players (29 matches - 23 for Montenegro and 6 for South Sudan) and Democracy (279 matches including South Sudan and 2 matches with Montenegro). This means that 2584 observations could be used for regressions ${ }^{3}$.

Tables 1 and 2 exhibit descriptive statistics for annual data per team $(\mathrm{n}=558$ observations) and differences between teams $(n=2584$ observations $)$, respectively. For the latter, we present the means and standard deviations of absolute values since they make more sense than actual values. Indeed, if we have for example two goal differences, one equal to 2 and the other equal to -2 , it makes no sense to calculate the mean of actual values (0) since it is not representative of the differences between teams (except if the two goal differences are related to games with the same teams $i$ and $j$ but this case, of course, cannot be generalised for the 2584 games in our sample).

\footnotetext{
${ }^{3}$ One game corresponds to one observation, i.e. if team $i$ defeats team $j$ by a score of $2-0,+2$ is recorded for the game between both teams. This game is not included a second time with both teams being inverted (the score becoming 0-2 and -2 being recorded). This would artificially increase both degrees of freedom and the variance of the independent variables, artificially increasing in turn the likelihood of rejecting the null hypothesis that any coefficient equals 0 .
} 
Table 1

Table 2

Correlations between variables for annual data per team and differences between teams are shown in Tables 3 and 4, respectively. FIFA points are strongly and positively correlated with Experience and Quality of Players $(\mathrm{r}>0.5)$. Other strong positive correlations in Table 3 are between Population and Experience, GDP and Democracy, and Democracy and Percentage of players. The strongest negative correlations in Table 3 are between GDP and CAF, and Percentage of players and AFC. In Table 4, if we exclude the strong positive correlations between Goal difference and Winner / draw, the only strong correlation is the positive relationship between FIFA point difference and Quality of players.

Table 3

Table 4

\section{Results}

The results are based on robust ordinary least squares (OLS) regressions for Goal difference and robust ordered logistic regressions for Winner / draw. Regressions were run with STATA 13.0. Prior to our main regressions, we tested our independent variables (other than game variables) to explain FIFA points at the end of 2011, 2012 and 2013. The aim was to make sure that our model is in line with previous ones interested in FIFA points in terms of explanatory 
power. The previous models with the best explanatory powers had $\mathrm{R}^{2}$ between 0.7 and 0.76 (Baur and Lehmann, 2007; Berlinschi et al., 2013; Gelade and Dobson, 2007; Leeds and Leeds, 2009). This is also what we found for our own regressions (Table 5).

Table 5

We then tested our two models for Goal difference and Winner / draw without FIFA point difference (Table 6). $\mathrm{R}^{2}$ for Goal difference is 0.29 whereas Pseudo- $\mathrm{R}^{2}$ for Winner / Draw is 0.14. All variables are significant in the Goal difference model except CONMEBOL. For Winner / draw, Climate and Percentage of players are not significant while Democracy and Prize difference for the underdog are significant only at the $10 \%$ threshold.

Table 6

Among the five variables related to sporting prizes, there is a clear hierarchy both for Goal difference and Winner / draw between Prize difference for the favourite (respectively $1.42 \pm 0.19$ and $1.55 \pm 0.22)$, Prize for both teams $(0.79 \pm 0.06$ and $0.91 \pm 0.07)$ and No prize in a friendly match $(0.48 \pm 0.06$ and $0.49 \pm 0.07)$. This hierarchy is logical: in the first case, the underdog has a smaller incentive to play its best compared to the second case; in the third case, both teams have a smaller incentive to play their best compared to the second case, which levels off the differences between them. It is not possible to establish a clear hierarchy with No prize in a competitive match and Prize difference for the underdog due to their standard errors being too large.

In a second set of regressions, FIFA point difference was added as explanatory variable so as to capture directly the differences in team strengths (Table 6). $\mathrm{R}^{2}$ for Goal difference is 
now 0.32 , meaning an increase of 0.03 , whereas Pseudo- $\mathrm{R}^{2}$ for Winner / draw is still 0.14 . Most of the variables are still significant in the Goal difference model (even CONMEBOL that was not previously significant) except Percentage of players and Quality of players while Income, Climate and Prize difference for the underdog are significant only at the $10 \%$ threshold. For Winner / draw, in addition to Climate and Percentage of players as for the previous results, Quality of players is not significant as for the Goal difference model; this is also the case for Prize difference for the underdog while Income is significant only at the $10 \%$ threshold. For the Goal difference model, it is worth noting that, although FIFA point difference has the strongest correlation with goal difference among explanatory variables (see Table 4), its incorporation does not add much to the explanatory power of the model. However, with FIFA point difference as explanatory variable alone, the Goal difference model has a better explanatory power $\left(\mathrm{R}^{2}=0.21\right)$ than with its 13 explanatory variables other than game variables $\left(\mathrm{R}^{2}=0.20\right)$

\section{Discussion and implications}

If most of the results are consistent with earlier studies, the significant negative impact of Democracy is at odds with Papanikos (2015) who has found it positive. Nevertheless, Papanikos (2015) has focused only on 32 teams and the 64 games of the 2014 World Cup. Moreover, he has found a significant negative impact for the square of democracy. It is worth noting that Democracy is not significant in the FIFA point model. An explanation could be that Democracy has a significant negative impact mainly in games that do not allocate a large number of FIFA points (e.g. friendly games against teams ranked $150^{\text {th }}$ and below). Contrary to previous studies where its impact was found significantly negative, Climate has an 
insignificant impact in the FIFA point model. Nevertheless, its impact is significantly negative in the Goal difference models.

Our confederation variables suggest the following hierarchy: 1. CONMEBOL, 2. CAF and UEFA, 4. CONCACAF, 5. AFC and OFC. This is rather consistent with Leeds and Leeds (2009) even if CAF was only $4^{\text {th }}$ in their findings (FIFA points in September 2006). Among our six newly-tested variables, the five related to sporting prizes have already been discussed in the Results section. As expected, Quality of players has a significant positive impact, except when FIFA point difference is included as explanatory variable. This is not surprising given the strong positive correlation between the two variables ( 0.53 ; see Table 4$)$.

The above-presented results have at least three implications for policymakers, national associations and football organisers. Percentage of players has a significant positive impact (except when FIFA point difference is included as explanatory variable). Thus, policymakers and national associations should encourage more people to play football if they want that their national team performs well, consistent with Gelade and Dobson (2007). Experience has also a significant positive impact and the strongest correlation with FIFA points. Consequently, national associations should play as many games as possible, especially those with limited experience. Nevertheless, it is not sure that national teams will gain as much experience if they play against teams with similar or weaker level than teams with higher level. Besides, playing as many games as possible is likely to be an inefficient strategy if teams play every two or three days.

Among sporting prizes, No prize in a friendly match has the lowest coefficient, meaning that the best team and certainly the underdog as well have a lower incentive to play their best. Considering that the objective of football organisers is to encourage teams to maximise their efforts, they should limit friendly games. Actually, UEFA has already decided to limit such friendly games in choosing to replace most of them by competitive ones with its Nations 
League that started in 2018 (UEFA, 2014). The results of this study provide an argument in favour of the decision made. Our results also show that Prize difference for the favourite has a higher coefficient than Prize for both teams (underdog likely not to play at its best without the incentive of a prize). Consequently, football organisers should try to ensure that each team is in contention for a sporting prize until the end of competition so as to provide teams with more incentives to play their best.

\section{Conclusion}

In this study, the determinants of national men's football team performance were investigated through goal differences instead of FIFA points as found in the literature. The advantages gained from retaining goal differences instead of FIFA points are a greater number of observations collected in the dataset and the possibility to test game specific variables such as different situations in terms of sporting prizes (two teams in contention, only one team in contention in distinguishing whether this is the favourite or the underdog, none of the two teams in contention in a competitive game, friendly game).

Based on all games over the 2011-2013 period, the results show that all the determinants tested are significant (except CONMEBOL). As a whole, the results of this study contribute to a better understanding of the determinants of national men's football team performance. Their implications could be useful for policymakers, national associations and football organisers. 


\section{References}

Allan, G.J. and Moffat, J. (2014) 'Muscle drain versus brain gain in association football: Technology transfer through player emigration and manager immigration', Applied Economics Letters, Vol. 21 No. 7, pp.490-493.

Andreff, W. and Andreff, M. (2015) 'Economic prediction of sport performances from Beijing Olympics to 2010 FIFA World Cup in South Africa: The notion of surprising sporting outcome', in Rodríguez, P., Késenne, S. and Koning, R. (Eds.), The Economics of Competitive Sport, Edward Elgar, Cheltenham, UK, pp.185-215.

Andreff, W. and Scelles, N. (2015) 'Walter C. Neale fifty years after: Beyond competitive balance, the league standing effect tested with French football data', Journal of Sports Economics, Vol. 16 No.8, pp.819-834.

Baur, D.G. and Lehmann, S. (2007) 'Does the mobility of football players influence the success of the national team?', IIIS Discussion Paper No. 217, Institute for International Integration Studies, Dublin.

Berlinschi, R., Schokkaert, J. and Swinnen, J. (2013) 'When drains and gains coincide: Migration and international football performance', Labour Economics, Vol. 21, pp.1-14.

Budzinski, O. and Pawlowski, T. (2014) 'The behavioural economics of competitive balance: Implications for league policy and championship management', Ilmenau Economics Discussion Papers, Vol. 19, No. 89, Institute of Economics, Ilmenau, Germany.

Buraimo, B. and Simmons, R. (2015) 'Uncertainty of outcome or star quality? Television audience demand for English Premier League football", International Journal of the Economics of Business, Vol. 22 No. 3, pp. 449-469. 
Congdon-Hohman, J. and Matheson, V.A. (2013) 'International women's soccer and gender inequality: Revisited', in M. Leeds and E. Marikova (Eds.), The Economics of Women's Sports, Edward Elgar, Cheltenham, UK, pp.345-364.

FIFA (n.d.) How are points calculated in the FIFA/Coca-Cola World Ranking? http://resources.fifa.com/mm/document/fifafacts/r\%26a-wr/52/00/97/fs590_10e_wrpoints_english.pdf(Accessed 8 September 2017).

Gelade, G.A. and Dobson, P. (2007) 'Predicting the comparative strengths of national football teams', Social Science Quarterly, Vol. 88 No. 1, pp.244-258.

Hoffmann, R., Ging, L.C. and Ramasamy, B. (2002) 'The socioeconomic determinants of international soccer performance', Journal of Applied Economics, Vol. 5 No. 2, pp.253272.

Hoffmann, R., Ging, L.C., Matheson, V. and Ramasamy, B. (2006) 'International women's football and gender inequality', Applied Economics Letters, Vol. 13 No. 15, pp.9991001.

Houston, R.G. and Wilson, D.P. (2002) 'Income, leisure and proficiency: An economic study of football performance', Applied Economics Letters, Vol. 9 No. 14, pp.939-943.

Jacobs, J.C. (2014) 'Programme-level determinants of women's international football performance', European Sport Management Quarterly, Vol. 14 No. 5, pp.521-537.

Kringstad, M. and Gerrard, B. (2004a) 'The concepts of competitive balance and uncertainty of outcome', in G.T. Papanikos (Ed.), The Economics and Management of Mega Athletic Events: Olympic Games, Professional Sports and Other Essays, ATINER, Athens, pp.115-130.

Kringstad, M. and Gerrard, B. (2004b) 'The concepts of competitive balance and uncertainty of outcome', International Association of Sports Economists Conference Paper, 0412. 
Kringstad, M. and Gerrard, B. (2005) 'Theory and evidence on competitive intensity in European soccer', International Association of Sports Economists Conference Paper, 0508 .

Kringstad, M. and Gerrard, B. (2007) 'Competitive balance in a modern league structure', Communication abstract at the North American Society for Sport Management Conference. May 30-June 2, 2007. Ft. Lauderdale, Florida.

Kuper, S. and Szymanski, S. (2012) Soccernomics, HarperSport, London.

Leeds, M.A. and Leeds, E.M. (2009) 'International soccer success and national institutions', Journal of Sports Economics, Vol. 10 No. 4, pp.369-390.

Macmillan, P. and Smith, I. (2007) 'Explaining international soccer rankings', Journal of Sports Economics, Vol. 8 No. 2, pp.202-213.

Monks, J. and Husch, J. (2009) 'The impact of seeding, home continent, and hosting on FIFA World Cup results', Journal of Sports Economics, Vol. 10 No. 4, pp.391-408.

Ozanian, M. (2013). Soccer's most valuable teams: At $\$ 3.3$ billion, Real Madrid knocks Manchester United from top spot, Forbes. http://www.forbes.com/sites/mikeozanian/2013/04/17/soccers-most-valuable-teamsreal-madrid-dethrones-manchester-united-from-top-spot-at-3-3-billion/\#76edc85b5348 (Accessed 8 September 2017).

Papanikos, G.T. (2015) 'Economic, population and political determinants of the 2014 World Cup match results', Soccer \& Society, Vol. 18 No. 4, pp.516-532.

Paul, S. and Mitra, R. (2008) 'How predictable are the FIFA worldcup football outcomes? An empirical analysis', Applied Economic Letters, Vol. 15 No. 15, pp.1171-1176.

Pawlowski, T. and Anders, C. (2012) 'Stadium attendance in German professional football: The (un)importance of uncertainty of outcome reconsidered', Applied Economics Letters, Vol, 19 No. 16, pp.1553-1556. 
Pawlowski, T. and Nalbantis, G. (2015) 'Competition format, championship uncertainty and stadium attendance: A small league perspective', Applied Economics, Vol. 47 No. 38, pp.4128-4139.

Pawlowski, T., Nalbantis, G. and Coates, D. (2018) 'Perceived game uncertainty, suspense and the demand for sport', Economic Inquiry, Vol. 56 No. 1, pp.173-192.

Scelles, N. (2017) 'Star quality and competitive balance? Television audience demand for English Premier League football reconsidered', Applied Economics Letters, Vol. 24 No. 19, pp.1399-1402.

Scelles, N., Desbordes, M. and Durand, C. (2011) 'Marketing in sport leagues: Optimising the product design. Intra-championship competitive intensity in French football Ligue 1 and basketball Pro A', International Journal of Sport Management and Marketing, Vol. 9 No. 1/2, pp.13-28.

Scelles, N., Durand, C., Bah S.T. and Rioult, F. (2011) 'Intra-match competitive intensity in French football Ligue 1 and rugby Top 14', International Journal of Sport Management and Marketing, Vol. 9 No. 3/4, pp.154-169.

Scelles, N., Durand, C., Bonnal, L., Goyeau, D. and Andreff, W. (2013a) 'Competitive balance versus competitive intensity before a match: Is one of these two concepts more relevant in explaining attendance? The case of the French football Ligue 1 over the period 20082011', Applied Economics, Vol. 45 No. 29, pp.4184-4192.

Scelles, N., Durand, C., Bonnal, L., Goyeau, D. and Andreff, W. (2013b) 'My team is in contention? Nice, I go to the stadium! Competitive intensity in the French football Ligue 1', Economics Bulletin, Vol. 33 No. 3, pp.2365-2378.

Scelles, N., Durand, C., Bonnal, L., Goyeau, D. and Andreff, W. (2016) 'Do all sporting prizes have a significant positive impact on attendance in a European national football league? Competitive intensity in the French Ligue 1', Ekonomicheskaya Politika / Economic 
Policy, Vol. 11 No. 3, pp.82-107. In Russian, English version at https://mpra.ub.uni$\underline{\text { muenchen.de/73844/ }}$

Torgler, B. (2004) 'The economics of the FIFA football worldcup', Kyklos, Vol. 57 No. 2, pp.287-300.

Torgler, B. (2008) 'The determinants of women's international soccer performances', International Journal of Sport Management and Marketing, Vol. 3 No. 4, pp.305-318.

UEFA (2014) UEFA Nations League format approved. http://www.uefa.org/aboutuefa/executive-

committee/news/newsid=2191264.html\#uefa + nations + league + format + schedule + appro ved (Accessed 8 September 2017).

Yamamura, E. (2009) 'Technology transfer and convergence of performance: An economic study of FIFA football ranking', Applied Economics Letters, Vol. 16 No. 3, pp.261-266.

Yamamura, E. (2012) 'Effect of linguistic heterogeneity on technology transfer: An economic study of FIFA football rankings', Atlantic Economic Journal, Vol. 40 No. 1, pp.85-99. 


\section{Tables}

Table 1. Descriptive statistics for annual data per team.

\begin{tabular}{|c|c|c|}
\hline Variable & Mean & SD \\
\hline FIFA points & 428.40 & 322.04 \\
\hline Population (in $1,000,000$ inhabitants) & 37.93 & 139.47 \\
\hline GDP per capita (in $1000 \$$ ) & 16.07 & 21.21 \\
\hline Democracy & 5.79 & 2.25 \\
\hline Temperature & 18.23 & 8.29 \\
\hline Climate & 86.68 & 66.94 \\
\hline Experience & 360.41 & 235.91 \\
\hline Percentage of players (in \%) & 5.35 & 3.38 \\
\hline Quality of players & 0.78 & 3.22 \\
\hline $\mathrm{AFC}$ & 0.24 & 0.42 \\
\hline CAF & 0.27 & 0.44 \\
\hline CONCACAF & 0.14 & 0.35 \\
\hline CONMEBOL & 0.05 & 0.23 \\
\hline OFC & 0.04 & 0.19 \\
\hline UEFA & 0.26 & 0.44 \\
\hline
\end{tabular}


Table 2. Descriptive statistics for differences between teams.

\begin{tabular}{|c|c|c|}
\hline Variable & Mean & SD \\
\hline Abs FIFA point difference & 240.02 & 222.24 \\
\hline Abs Goal difference & 1.48 & 1.41 \\
\hline Abs Winner / draw & 0.75 & 0.43 \\
\hline Abs Population difference (in $1,000,000$ & 73.02 & 213.26 \\
\hline \multicolumn{3}{|l|}{ inhabitants) } \\
\hline Abs GDP per capita difference (in $1000 \$$ ) & 16.75 & 21.83 \\
\hline Abs Climate difference & 61.80 & 65.93 \\
\hline Abs Democracy difference & 1.86 & 1.52 \\
\hline Abs Experience difference & 184.40 & 141.89 \\
\hline Abs Percentage of players difference (in \%) & 2.56 & 3.22 \\
\hline Abs Quality of players difference & 1.61 & 4.35 \\
\hline $\mathrm{Abs} \mathrm{AFC}^{1}$ & 0.05 & 0.22 \\
\hline Abs $\mathrm{CAF}^{1}$ & 0.03 & 0.17 \\
\hline Abs CONCACAF ${ }^{1}$ & 0.05 & 0.22 \\
\hline Abs CONMEBOL ${ }^{1}$ & 0.06 & 0.24 \\
\hline $\mathrm{Abs}_{\mathrm{OFC}}{ }^{1}$ & 0.01 & 0.08 \\
\hline Abs UEFA ${ }^{1}$ & 0.07 & 0.25 \\
\hline Abs Home advantage & 0.75 & 0.44 \\
\hline Abs Prize for both teams & 0.47 & 0.50 \\
\hline Abs Prize difference for the favourite & 0.04 & 0.21 \\
\hline Abs Prize difference for the underdog & 0.01 & 0.11 \\
\hline Abs No prize in competitive match & 0.03 & 0.17 \\
\hline Abs No prize in friendly match & 0.38 & 0.48 \\
\hline
\end{tabular}

${ }^{1}$ Different from 0 only for inter-confederations games ( 1 if at home, -1 if away). 
Table 3. Correlations for annual data per team.

\begin{tabular}{|l|l|l|l|l|l|l|l|l|l|l|l|l|l|}
\multicolumn{1}{c|}{} & FIFA & POP & GDP & DEM & CLI & EXP & PPL & QPL & AFC & CAF & CON & CSF & OFC \\
\hline POP & $.41^{* *}$ & & & & & & & & & & & & \\
\hline GDP & $.30^{* *}$ & $-.29^{* *}$ & & & & & & & & & & & \\
\hline DEM & $.26^{* *}$ & $-.28^{* *}$ & $.63^{* *}$ & & & & & & & & & & \\
\hline CLI & $-.25^{* *}$ & $-.13^{* *}$ & $-.11^{* *}$ & $-.09^{*}$ & & & & & & & & & \\
\hline EXP & $.70^{* *}$ & $.61^{* *}$ & $.22^{* *}$ & $.14^{* *}$ & $-.26^{* *}$ & & & & & & & & \\
\hline PPL & $.34^{* *}$ & $-.26^{* *}$ & $.36^{* *}$ & $.54^{* *}$ & -.05 & $.14^{* *}$ & & & & & & & \\
\hline QPL & $.53^{* *}$ & $.21^{* *}$ & $.22^{* *}$ & $.20^{* *}$ & $-.19^{* *}$ & $.27^{* *}$ & $.19^{* *}$ & & & & & & \\
\hline AFC & $-.33^{* *}$ & $.23^{* *}$ & -.04 & $-.31^{* *}$ & -.001 & $-.09^{*}$ & $-.51^{* *}$ & $-.13^{* *}$ & & & & & \\
\hline CAF & $-.10^{*}$ & $.10^{*}$ & $-.59^{* *}$ & $-.40^{* *}$ & $.17^{* *}$ & $-.11^{* *}$ & $-.15^{* *}$ & $-.12^{* *}$ & $-.34^{* *}$ & & & & \\
\hline CON & $-.14^{* *}$ & $-.33^{* *}$ & $.17^{* *}$ & $.26^{* *}$ & $.25^{* *}$ & $-.25^{* *}$ & $.33^{* *}$ & $-.10^{*}$ & $-22^{* *}$ & $-.24^{* *}$ & & & \\
\hline CSF & $.32^{* *}$ & $.13^{* *}$ & .04 & $.09^{*}$ & $-.09^{*}$ & $.21^{* *}$ & $.20^{* *}$ & $.11^{* *}$ & $-.13^{* *}$ & $-.15^{* *}$ & $-.10^{*}$ & & \\
\hline OFC & $-.18^{* *}$ & $-.27^{* *}$ & $.08^{+}$ & $.15^{* *}$ & .003 & $-.28^{* *}$ & .02 & -.05 & $-.11^{* *}$ & $-.12^{* *}$ & -.08 & -.05 & \\
\hline UEFA & $.44^{* *}$ & -.01 & $.44^{* *}$ & $.39^{* *}$ & $-.33^{* *}$ & $.42^{* *}$ & $.28^{* *}$ & $.29^{* *}$ & $-.33^{* *}$ & $-.36^{* *}$ & $-.24^{* *}$ & $-.14^{* *}$ & $-.12^{* *}$ \\
\hline
\end{tabular}

${ }^{+} p<.1 ; * p<.05 ; * * p<.01$. 
Table 4. Correlations for differences between teams.

\begin{tabular}{|c|c|c|c|c|c|c|c|c|c|c|c|c|c|c|c|c|c|c|c|c|c|}
\hline & FIFA & GD & WD & POP & GDP & DEM & CLI & EXP & PPL & QPL & AFC & CAF & $\mathrm{CON}$ & CSF & OFC & UEFA & HA & PBT & PDF & PDU & NPC \\
\hline GD & $.46^{* *}$ & & & & & & & & & & & & & & & & & & & & \\
\hline WD & $.41 * *$ & $.82 * *$ & & & & & & & & & & & & & & & & & & & \\
\hline POP & $.36^{* *}$ & $.29 * *$ & $.25 * *$ & & & & & & & & & & & & & & & & & & \\
\hline GDP & $.19^{* *}$ & $.09 * *$ & $.10^{* *}$ & $-.24 * *$ & & & & & & & & & & & & & & & & & \\
\hline DEM & $.17^{* *}$ & .03 & $.04 *$ & $-.07 * *$ & $.43 * *$ & & & & & & & & & & & & & & & & \\
\hline CLI & $-.08^{* *}$ & $-.06^{* *}$ & $-.05^{*}$ & -.01 & $.06^{* * *}$ & $-.04 *$ & & & & & & & & & & & & & & & \\
\hline EXP & $.41^{* *}$ & $.35^{* *}$ & $.30^{* *}$ & $.45^{* *}$ & $.14 * *$ & $.18^{* *}$ & -.01 & & & & & & & & & & & & & & \\
\hline PPL & $.18^{* *}$ & $.07 * *$ & $.07 * *$ & $-.11 * *$ & $.13^{* *}$ & $.24 * *$ & $-.06^{* *}$ & .01 & & & & & & & & & & & & & \\
\hline QPL & $.53 * *$ & $.22 * *$ & $.21^{* *}$ & $.23 * *$ & $.13 * *$ & $.10^{* *}$ & $-.11^{* *}$ & $.13^{* *}$ & $.07 * *$ & & & & & & & & & & & & \\
\hline AFC & $-.12 * *$ & $-.08 * *$ & $-.04^{+}$ & $.09 * *$ & $.08^{* *}$ & $-.09 * *$ & $-.03^{+}$ & -.01 & $-.25^{* *}$ & $-.09 * *$ & & & & & & & & & & & \\
\hline CAF & -.02 & .01 & -.02 & .02 & $-.18^{* *}$ & $-.07 * *$ & $.05 * *$ & $-.04 *$ & $.04 *$ & $-.05^{*}$ & $-.39^{* *}$ & & & & & & & & & & \\
\hline $\mathrm{CON}$ & $-.07^{* *}$ & $-.08^{* *}$ & $-.08^{* *}$ & .003 & $\begin{array}{l}-.01 \\
\end{array}$ & $.04 *$ & $.15^{* *}$ & $\begin{array}{l}-.03 \\
\end{array}$ & $.09^{* *}$ & $-.11 * *$ & $-11^{* *}$ & $-.04^{+}$ & & & & & & & & & \\
\hline CSF & $.09^{* *}$ & $.13 * *$ & $.12 * *$ & .03 & $-.03^{+}$ & $\begin{array}{l}-.01 \\
\end{array}$ & $\begin{array}{l}-.01 \\
\end{array}$ & $.05^{*}$ & .03 & $\begin{array}{l}-.01 \\
\end{array}$ & $-.10^{* *}$ & $-.14 * *$ & $-.45^{* *}$ & & & & & & & & \\
\hline$\overline{\text { OFC }}$ & $-.06^{* *}$ & $-.06 * *$ & $-.03^{+}$ & $-.09^{* *}$ & $.05^{* *}$ & $.10^{* *}$ & $-.05^{*}$ & $-.07 * *$ & .02 & $-.03^{+}$ & $-.15 * *$ & -.03 & $-.15^{* *}$ & $\begin{array}{l}-.02 \\
\end{array}$ & & & & & & & \\
\hline UEFA & $.11 * *$ & .02 & .01 & $-.09^{* *}$ & $.07 * *$ & $.06^{* *}$ & $-.11^{* *}$ & $.03^{+}$ & $.08^{* *}$ & $.20^{* *}$ & $-.37^{* *}$ & $-.16^{* *}$ & $-.26^{* *}$ & $-.33^{* *}$ & -.02 & & & & & & \\
\hline HA & $-.07 * *$ & $.09 * *$ & $.08^{* *}$ & .01 & $.04 *$ & -.02 & $\begin{array}{l}-.01 \\
\end{array}$ & -.003 & -.03 & $-.06 * *$ & $.07 * *$ & .004 & $-.06^{* *}$ & -.03 & .01 & .002 & & & & & \\
\hline $\begin{array}{l}\text { PBT } \\
\end{array}$ & $.43^{* *}$ & $.36^{* *}$ & $.37 * *$ & $.26^{* *}$ & $.11^{* *}$ & $.06^{* *}$ & -.02 & $.32^{* *}$ & $.07 * *$ & $.19^{* *}$ & $\begin{array}{l}-.02 \\
\end{array}$ & .02 & $\begin{array}{l}-.02 \\
\end{array}$ & .03 & $\begin{array}{l}-.02 \\
\end{array}$ & \begin{tabular}{l|l|}
-.01 \\
\end{tabular} & $.07 * *$ & & & & \\
\hline PDF & $.21 * *$ & $.19 * *$ & $.17^{* *}$ & $.12^{* *}$ & .03 & .02 & -.01 & $.13^{* *}$ & .003 & $.07 * *$ & -.001 & .002 & -.0003 & .01 & -.02 & -.001 & .01 & -.01 & & & \\
\hline PDU & $.11^{* *}$ & $.07 * *$ & $.05^{* *}$ & $.07 * *$ & $.04^{+}$ & $.05^{*}$ & -.03 & $.05^{*}$ & .03 & $.08^{* *}$ & -.001 & .003 & -.0004 & .001 & .001 & -.002 & $.05 *$ & -.01 & -.001 & & \\
\hline NPC & $.09^{* *}$ & $.08^{* *}$ & $.07 * *$ & $.07 * *$ & .01 & $\begin{array}{l}-.02 \\
\end{array}$ & .003 & $.07 * *$ & $\begin{array}{l}-.01 \\
\end{array}$ & .02 & $\begin{array}{l}-.002 \\
\end{array}$ & .004 & $\begin{array}{l}-.001 \\
\end{array}$ & .02 & $\begin{array}{l}-.03 \\
\end{array}$ & $\begin{array}{l}-.01 \\
\end{array}$ & .01 & -.01 & -.001 & -.001 & \\
\hline NPF & $.34 * *$ & $.21 * *$ & $.20 * *$ & $.15^{* *}$ & $.13 * *$ & .02 & $-.04^{+}$ & $.18^{* *}$ & $.05^{*}$ & $.19^{* *}$ & $-.05 * *$ & $-.06 * *$ & $-.12^{* *}$ & $.14^{* *}$ & $-.06 * *$ & $.07 * *$ & $.05 * *$ & $-.07 * *$ & -.01 & -.01 & -.01 \\
\hline
\end{tabular}

${ }^{+} p<.1 ; * p<.05 ; * * p<.01$. 
Table 5. Results for FIFA points.

\begin{tabular}{|c|c|c|c|}
\hline Variable & 2011 & 2012 & 2013 \\
\hline Population & $31.27(10.53) * * *$ & $37.25(10.43) * * *$ & $35.06(11.32) * * *$ \\
\hline Income & $39.28(11.22) * * *$ & $39.33(12.46) * * *$ & $38.89(12.28) * * *$ \\
\hline Democracy & $-0.62(8.71)$ & $-9.59(9.05)$ & $-6.94(8.55)$ \\
\hline Climate & $-0.14(0.24)$ & $0.02(0.26)$ & $-0.22(0.23)$ \\
\hline Experience & $123.53(20.40) * * *$ & $118.82(22.80) * * *$ & $124.42(22.78) * * *$ \\
\hline Percentage of players & $913.34(464.13) *$ & $982.29(567.10) *$ & $955.89(530.41) *$ \\
\hline Quality of players & $28.10(7.46) * * *$ & $28.99(5.05) * * *$ & $23.92(5.26) * * *$ \\
\hline AFC & $-321.19(76.77) * * *$ & $-395.94(84.83) * * *$ & $-413.32(76.88) * * *$ \\
\hline CAF & $-166.60(75.33) * *$ & $-190.86(80.17) * *$ & $-219.41(76.02) * * *$ \\
\hline CONCACAF & $-197.40(72.41) * * *$ & $-206.33(79.71) * * *$ & $-262.34(79.87) * * *$ \\
\hline CONMEBOL & & ref. & \\
\hline OFC & $-271.04(81.81) * * *$ & $-225.85(92.89) * *$ & $-290.32(87.28) * * *$ \\
\hline UEFA & $-141.93(75.68) *$ & $-165.57(75.99) * *$ & $-183.99(73.09) * *$ \\
\hline Constant & $-949.12(212.87) * * *$ & $-958.43(196.25) * * *$ & $-916.07(208.01) * * *$ \\
\hline Observations & & 186 & \\
\hline $\mathrm{R}^{2}$ & 0.73 & 0.71 & 0.72 \\
\hline
\end{tabular}

For each variable, its coefficient is indicated with its standard error in brackets. $* p<.1 ; * * p<.05 ; * * * p<.01$. 
Table 6. Results for goal difference and team $i$ / draw / team $j$ without then with FIFA point difference.

\begin{tabular}{|c|c|c|c|c|}
\hline \multirow[t]{2}{*}{ Variable } & \multicolumn{2}{|c|}{ Without FIFA point difference } & \multicolumn{2}{|c|}{ With FIFA point difference } \\
\hline & Goal difference & Winner / draw & Goal difference & Winner / draw \\
\hline Population & $0.09(0.02) * * *$ & $0.09(0.02) * * *$ & $0.07(0.02) * * *$ & $0.07(0.03) * * *$ \\
\hline Income & $0.07(0.03) * * *$ & $0.07(0.03) * *$ & $0.05(0.03) *$ & $0.06(0.03) *$ \\
\hline Democracy & $-0.05(0.02) * * *$ & $-0.03(0.02) *$ & $-0.06(0.02) * * *$ & $-0.04(0.02) * *$ \\
\hline Climate & $-0.0008(0.0004) * *$ & $-0.0007(0.0004)$ & $-0.0007(0.0004) *$ & $-0.0006(0.0005)$ \\
\hline Experience & $1.84(0.31) * * *$ & $1.53(0.32) * * *$ & $1.53(0.31) * * *$ & $1.23(0.32) * * *$ \\
\hline Percentage of players & $1.54(0.87) *$ & $1.73(1.12)$ & $0.75(0.87)$ & $1.21(1.15)$ \\
\hline Quality of players & $0.03(0.01) * * *$ & $0.04(0.01) * * *$ & $-0.004(0.01)$ & $0.01(0.01)$ \\
\hline $\mathrm{AFC}$ & $-1.62(0.33) * * *$ & $-7.94(0.46) * * *$ & $-1.61(0.30) * * *$ & $-7.92(0.45) * * *$ \\
\hline CAF & $-0.91(0.33) * * *$ & $-7.72(0.48) * * *$ & $-1.03(0.30) * * *$ & $-7.79(0.46) * * *$ \\
\hline CONCACAF & $-1.09(0.32) * * *$ & $-7.82(0.47) * * *$ & $-1.19(0.28) * * *$ & $-7.88(0.45) * * *$ \\
\hline CONMEBOL & $-0.33(0.29)$ & $-6.88(0.43) * * *$ & $-0.50(0.25) * *$ & $-6.98(0.41) * * *$ \\
\hline $\mathrm{OFC}$ & $-1.83(0.80) * *$ & $-7.81(0.70) * * *$ & $-1.80(0.76) * *$ & $-7.79(0.68) * * *$ \\
\hline UEFA & $-1.04(0.29) * * *$ & $-7.68(0.43) * * *$ & $-1.15(0.24) * * *$ & $-7.76(0.41) * * *$ \\
\hline Home advantage & $0.30(0.08) * * *$ & $0.27(0.09) * * *$ & $0.38(0.08) * * *$ & $0.36(0.09) * * *$ \\
\hline Prize for both teams & $0.79(0.06) * * *$ & $0.91(0.07) * * *$ & $0.58(0.06) * * *$ & $0.72(0.07) * * *$ \\
\hline Prize for favourite & $1.42(0.19) * * *$ & $1.55(0.22) * * *$ & $1.09(0.19) * * *$ & $1.28(0.22) * * *$ \\
\hline Prize for underdog & $0.83(0.31) * * *$ & $0.67(0.37) *$ & $0.56(0.30) *$ & $0.43(0.36)$ \\
\hline No prize in competitive & $0.70(0.24) * * *$ & $0.70(0.24) * * *$ & $0.50(0.24) * *$ & $0.49(0.25) * *$ \\
\hline No prize in friendly & $0.48(0.06) * * *$ & $0.49(0.07) * * *$ & $0.29(0.06) * * *$ & $0.32(0.08) * * *$ \\
\hline FIFA point & & & $0.001(0.0002) * * *$ & $0.001(0.0002) * * *$ \\
\hline Constant & $0.01(0.07)$ & & $0.01(0.07)$ & \\
\hline Observations & & & & \\
\hline $\mathrm{R}^{2} /$ Pseudo-R ${ }^{2}$ & 0.29 & 0.14 & 0.32 & 0.14 \\
\hline
\end{tabular}

For each variable, its coefficient is indicated with its standard error in brackets. ${ }^{*} p<.1 ; * * p<.05 ; * * * p<.01$. 